\title{
Article
}

\section{Comparing vocabulary learning of EFL learners by using two different strategies: mobile learning vs. flashcards}

\author{
Behrooz Azabdaftari and Mohammad Amin Mozaheb* \\ Islamic Azad University, Tabriz Branch (Iran)
}

*mozaheb.ma @ gmail.com

\begin{abstract}
Vocabulary acquisition is one of the most important aspects of language learning. There are a number of techniques and technologies which enhance vocabulary learning in the year 2012, e.g. wordlists, flashcards and m-learning. Mobile phones are among those devices which not only meet the expectations of their users for communication, but are also good devices for language learning. Mobile phones can be used anywhere and anytime, and students are free to use them inside or outside the classroom setting. The present study compared the use of two strategies for vocabulary learning (i.e. flashcards and m-learning) among 80 students studying English Literature and Translation at BA level in a non-profit, non-governmental university in the city of Tehran, the capital of Iran. The findings showed that the use of mobile phones for language learning and vocabulary learning would be a better strategy compared to the use of other paramount techniques, such as flashcards.
\end{abstract}

Key words: Vocabulary learning, flashcards, mobile phones, CALL, Language learning. 


\section{Introduction}

Vocabulary learning is an integral part of language teaching. How the vocabulary should be learned or acquired in Second/Foreign language contexts is a question which needs further research studies (e.g., Folse, 2004; Hunt \& Belgar, 2005). Recently, vocabulary teaching has become the topic of interest for many ESL/EFL practitioners all around the world (e.g., Calderon et al., 2005; Cheung \& Slavin, 2005; Folse, 2006; Lee \& Muncie, 2006; Nassaji, 2003). Nam (2010: 127) stressed that "not only vocabulary supports the four language skills of listening, speaking, reading, and writing, but also mediates between ESL students and content-area classes in that these students often find that lack of vocabulary knowledge is an obstacle to learning". Moreover, the more vocabulary an ESL/EFL learner acquires, the better communication he/she will have. There are a large number of strategies and techniques utilized by teachers in teaching vocabulary. These techniques are used to foster the ESL/EFL learners' ability to convey their intended meanings in different contexts and settings.

If learners do not acquire effective strategies for learning new vocabularies, they will be disappointed and will lose their self-confidence (Nation, 2001). Consequently, it is necessary for ESL/EFL practitioners to familiarize students with new strategies and techniques which are used for vocabulary learning (Baleghizadeh \& Ashoori, 2011, Hulstijn, 2001; Hulstijn, and Laufer, 2001). The current study will introduce and compare two different techniques (i.e. mobile learning (m-Learning) vs. flashcards) for vocabulary teaching for EFL students.

\subsection{Vocabulary teaching}

Many ESL/EFL teachers are asked by their students about the best way of learning vocabularies in ESL/EFL contexts. Most learners are not aware of the different strategies for learning vocabularies. The role of teachers in informing their students with regard to proper strategies for vocabulary learning cannot be ignored. In other words, it is the duty of ESL/EFL teachers to acquaint the learners with new strategies in vocabulary learning.

Breadth and depth are two dimensions of vocabulary learning (Qian, 2002; Read, 1988; Wesche \& Paribakht, 1996). Breadth refers to the vocabulary size of each ESL/EFL learner and it relates to the recognition and production of lexical items. On the other hand, depth concentrates on how well a learner knows a word. Reading can foster both breadth and depth of vocabulary learning. Each ESL/EFL teacher should consider these two dimensions of vocabulary learning while employing different strategies for vocabulary teaching.

Another important dimension with regard to vocabulary learning is the one introduced by Oxford and Scarcella (1994) in which there are three categories for vocabulary learning, namely decontextualized vocabulary items (often having no context for guiding the learners to learn the meaning and function of the new words, e.g. flashcards, wordlists), partially contextualized vocabulary items (technically called planned or intentional vocabulary items e.g., word association, word groupings, physical responses) and ultimately, fully contextualized vocabulary activities ( providing students with authentic practices for the newly-learned vocabulary item, e.g. participating in 
conversations, writing messages with the purpose of real world or authentic communication, listening to the radio or MP3 files).

As mentioned earlier, vocabulary learning can be fostered by reading since reading can provide multiple encounters with the newly-acquired vocabulary items (Nagy, Herman, Anderson, 1985). Flashcards are a sample of decontextualized vocabulary activities while mobile learning (m-learning) can be viewed as an instance of fully contextualized vocabulary activities.

\subsection{Mobile Learning (m-Learning)}

Larsen-Freeman and Anderson (2011) name a number of techniques which are used for language learning in the age of technology such as :blogs, computer-assisted language learning software, mobile phones, digital portfolios, distance education, electronic chatting, e-pen pals, electronic presentation, electronic text corpora, cell phone-based applications: text messaging and twitter, podcasts, social networking and wikis. Among these techniques, mobile phones are one of the most important ones. Learning anywhere and anytime is the most important advantage of wireless mobile technologies such as cellular phones, iPods, Personal Digital Assistants (PDAs), ultra notebook computers which are paramount everywhere. The importance of Mobile learning is the fact that the learning is delivered to the "right person, at the right time and in the right place while using electronic devices" (Ally et al., 2007: 2). Thanks to the speed of innovation in new technologies, mobile learning will be the focal point in education in the near future.

Mobile learning (m-learning) is a new concept in the world of ESL/EFL. Considering this point, one cannot find many studies with regard to m-learning (i.e., Attewell, 2005; British Educational Communications Technology Agency, 2004; Keegan, 2002; SavillSmith \& Kent, 2003). The initial investigation of m-learning in education demonstrated a number of drawbacks to the use of mobile devices in educational settings, e.g. having a small screen, having limited processing power, having limited battery life, having limited memory capacity (Holzinger, Nischelwitzer, \& Meisenberger, 2005). In the year 2012, the new mobile phone companies solved most of these problems, and now the use of finger touch phones with wide screens using Android or Windows Mobile is very common all over the world.

Recent research studies show that the use of m-learning can increase the motivation of learners and improve their writing and grammar skills as well (Ally, et al., 2007). It should be noted that familiarization with the new mobile devices needs time and energy. In other words, there should be some technical staff to assist the learners when they encounter different problems (British Educational Communications Technology Agency, 2004).

There are a number of studies with regard to the use of $\mathrm{m}$-learning in teacher education (e.g., Brown, 2004; Perry, 2000; Stockwell, 2007 \& 2008; Taylor, 2005; White, 2005). Additionally, Song and Fox (2005) used m-learning with task-based language learning (TBLL) in ESL settings and found a great improvement in the performance of students. Other studies showed a significant improvement in the use of mobile devices for listening and pronunciation teaching (e.g., Bull, et al., 2005). There are a number of other research studies with regard to the use of mobile devices in different processes of language learning, such as the use of meta data and online learning ( see for example, Ally, 2004; Davis, Good \& Sarvas, 2004; Esmahi \& Lin, 2004; Lin, 2004; Lin \& Esmahi, 2004; Kawarasaki, et al., 2004; Magusin, Johnson \& Tin, 2003; McGreal, et al., 2005; McGreal, et al., 2005; Yang, Shao \& Sue, 2005).

Accordingly, in a seminal volume the ReCALL journal published a number of research studies about the use of Mobile Assisted Language Learning (MALL) in EFL/ESL settings. For instance, Song and Fox (2008: 291) stressed that "PDAs can be used in more flexible, novel and extended ways for English as a Foreign Language (EFL) vocabulary teaching and learning in higher education" while regarding the students' needs. In 
another study, Kennedy and Levy (2008) posited that the use of SMS would be a good tool for vocabulary learning in EFL contexts. Nah, White and Sussex (2008:335) hold that the use of WAP sites "can enhance opportunities to learn language skills, and encourage language learners to participate actively in the learning process". Furthermore, Wishart (2008) carried out a research study on a new line of research in the domain of MALL. Wishart (2008: 349) investigated "challenges faced by modern foreign language teacher trainees in using handheld pocket PCs (Personal Digital Assistants) to support their teaching and learning". In the mentioned study, Wishart (2008) meticulously explored the issue and found a coherent framework with regard to the use of PDAs in ESL/EFL classrooms. Petersen, Divitiny and Chabert (2008) analyzed the concept of identity in a community of mobile language learners. In other words, Petersen, Divitiny and Chabert (2008: 378) suggest that "while a blog might be an appropriate tool for promoting knowledge sharing, it lacks functionalities to promote connectedness among learners and foster their identity as a community." Last but not least, Kukulska-Hulmea and Shielda (2008) did an in depth analysis of MALL in ESL settings. To put it other way, they were "interested in speaking and listening practice and in the possibilities for both synchronous and asynchronous interaction in the context of online and distance learning." Kukulska-Hulmea and Shielda (2008: 288)

\subsection{Flashcards}

Flashcards are another technique for ESL/EFL learners while learning new vocabularies. A flashcard "is a cardboard consisting of a word, a sentence, or a simple picture on it" (Baleghizadeh \& Ashoori, 2011: 2). Another important feature of these cards is the fact that all the letters should be written in capital letters because learners sitting both in the front and back of the classroom should be able to read them easily. In the process of teaching vocabulary to ESL/EFL students, both sides of these cards should be used. In other words, on the one side the new vocabulary item should be written in the second language and on the other side should be written the translation and pronunciation. In some cases, a sample sentence from the dictionary would pave the way for vocabulary learning. Both teachers and learners can devise their own flashcards. Needless to say, nowadays there are many ready-made flashcards on the market which can be used as a guide for self-study in EFL settings.

Having reviewed the related literature on the use of flashcards in ESL/EFL contexts, it was found that flashcards have a long history for both teaching and learning purposes. Compared to wordlists, (another strategy for learning vocabulary), flashcards are more effective in terms of learning (e.g., Akın \& Seferoğlu, 2004; Bruton, 2007; Erten \& Tekin, 2008; Genç, 2004; McCarten, 2007; Moras, 2001; Newton, 2001; Tang \& Nesi, 2003). Moreover, they were used for teaching alphabets in both L1 and L2 contexts (e.g., Young, Hecimovic \& Salzberg, 1983). In particular, flashcards are used in SL contexts for teaching vocabularies, articles, structures and phrasal verbs (Palka, 1988).

Although the use of flashcards for language learning dates back many years, the number of research studies done in this area is limited. Ehri \& Roberts (1979) used flashcards for teaching alphabets and new words in contexts. They showed that the use of flashcards would be very helpful in language learning. In another study, McCullough (1995) stressed that the use of flashcards is helpful for language learning but that the main emphasis of flashcards is memorization, not comprehension. Some other researchers believe that flashcards are good for children, not adult learners, and they can create fun classrooms (Nicholson, 1998).

\section{The current study}

Having viewed the related literature on MALL and ESL/EFL contexts, it was found that the use of the Internet, PDAs, online dictionaries and SMS in language learning has not been investigated simultaneously. This study aims to fill the mentioned gap in an Iranian setting which can be used in other ESL /EFL settings as well. To put it simply, the current study compares two strategies used for vocabulary teaching in EFL settings, i.e., flashcards vs. m-learning. There are some reasons behind this comparison. The 
related literature on the use of flashcards in ESL/EFL contexts shows that there are limited studies done in this area and as to whether flashcards are useful for the vocabulary learning of FL learners. It is also believed that using m-learning and PDAs in second language settings has many advantages (Kukulska-Hulme, 2009). However, in some cases the use of mobile phones for vocabulary learning was insignificant as reported by Okunbor and Retta (2008). These results cannot fill the gap in this regard, so further research studies would pave the way for answering the question of whether $\mathrm{m}$-learning is useful for teaching vocabulary in SL contexts. Additionally, the number of studies in Iran is very limited with regard to the use of m-learning in language learning. Hence, this study seeks to determine the effectiveness of m-learning in vocabulary learning. Considering the mentioned point, this study investigates the following research questions.

1. Which strategy of vocabulary learning (e.g. flashcards vs. m-learning) is more effective in terms of learning the newly-introduced vocabularies for Iranian EFL learners?

2. What are the advantages and disadvantages of the vocabulary techniques (e.g. flashcards vs. m-learning) utilized in the present study on the basis of the learner's experience?

3. Method

\subsection{Context of the study}

The present study was carried out at a non-profit, non-governmental university in the city of Tehran (capital of Iran) with undergraduates of Translation and English Literature. All of them passed the Konkoor (an annual university entrance examination held nationwide in Iran). These students should master the four skills of speaking, writing, listening and reading during the four years of study. Vocabulary learning is one of the focal points which should be mastered during these four years of study. It is also important to note that the language proficiency level of these students was upperintermediate and they were homogeneous in nature, since all of them passed the Konkoor, which is a validated examination in which the four skills are assessed for those who would like to continue their higher education in English majors.

\subsection{Participants}

The participants were 80 students studying English literature and Translation at BA level in a non-profit, non-governmental university in the city of Tehran, the capital of Iran. As mentioned earlier, these students passed the Konkoor and were homogenous in nature, and their preferences and scores were the critical issues for allowing them to enter the university. Their mean age was 20.5 and the level of their English proficiency based on TOEFL (IBT) was 90. Among these students, 40 of them were selected as the experimental group with regard to the fact that their mobile phones should be compatible with the vocabulary learning program. It is interesting to note that about 25 of them had PDAs and it was easy for them to use the vocabulary program and access the Internet. Additionally, 40 of them were selected as the control group.

\subsection{Research Design}

In this study, both qualitative and quantitative methods of data collection were used to investigate the effectiveness of using two vocabulary techniques, i.e. m-learning and flashcards, on the level of vocabulary learning of EFL students. New vocabularies were taught to the students in the experimental group (those who used m-learning) and the control group (those who used flashcards) within a 7-week period. The SRS (Spaced Repetition System) vocabulary acquisition program was selected to be used as the Mobile software for this study. The required vocabularies were scanned and inserted into the system and then the program was used as the main software for teaching the new vocabularies. It is also important to note that in addition to this software, Short 
Message Services (SMS) and the Internet were used where the teacher thought they would be necessary and helpful for vocabulary learning. The control group used only the paper flashcards during the seven weeks of the study. Some of the covered topics were sports, entertainment, going abroad and favourite hobbies. During these seven weeks about 1200 new words were introduced to the students.

Before starting the experiment, the main aims of the study were meticulously described to the students. During the seven weeks, the students had to use the vocabulary program both inside and outside the classroom, and they had to answer the SMS sent to them by the teachers. Sometimes they had to listen to some useful files sent to them via Bluetooth for increasing their understanding of the newly-learned vocabularies. On the other hand, students in the control group utilized the paper flashcards for learning the new vocabularies. On the one side they had the new word and the pronunciation, and on the other side the meaning of the word in their mother tongue and L2 as well. To assess the newly-learned vocabularies, a validated multiple choice test was administered after the study. Afterwards, to find the answer for the two research questions, the qualitative method was used to interview 10 students from the experimental group with regard to the use of $\mathrm{m}$-learning in $\mathrm{FL}$ vocabulary learning and 10 students from the control group who used the flashcards as the main strategy for learning new vocabularies. It is important to note that the students were selected randomly and all the interviews were recorded with an MP4.

\section{Data Collection Instrument}

To assess the newly-learned vocabularies, a multiple-choice test was conducted. The frequent vocabularies in the mobile program and flashcards were realized, and initially the test was designed with 100 items. To pilot the test and to increase the internal consistency, the test was administered to 40 students taking the same course. The measure of internal consistency of the devised test was 0.795 . Then, the final version was designed with only 20 multiple-choice items. This test was administered to the control and experimental groups after the treatment.

\section{Data Analysis}

In this study, each correct response had five points. The range of the scores was 0 to 100. In order to answer the research questions for the quantitative data, an independent sample t-test in addition to descriptive statistics was utilized. Afterwards, in the qualitative phase of the study, the researchers conducted semi-structured interviews with ten students from the experimental group with regard to the use of $\mathrm{m}$ learning for vocabulary instruction and ten students from the control group with regard to their experience in learning vocabularies by using flashcards. Then, the main themes realized from the interviews with regard to the use of m-learning and flashcards were discussed.

\section{Results}

To answer the first research question, (i.e., which strategy of vocabulary learning (e.g. flashcards vs. m-learning) is more effective in terms of learning the newly-introduced vocabularies for Iranian EFL learners?) an independent t-test was run. Based on the findings in Table 1 above, it was revealed that the mean calculated for the experimental group, i.e. (65), is statistically higher than the mean of the control group, i.e. (45). In other words, there is a significant difference between these two means, as ( $t(78)=$ $6.99, \mathrm{p}<0.05$ ). This finding shows that the use of m-learning (vocabulary learning program) improves the level of the learned vocabularies of the students more than the flashcards.

\begin{tabular}{|c|l|}
\hline Control group who used (flashcards) & Experimental group who used (m-learning) \\
\hline $\mathrm{N}=40$ & $\mathrm{~N}=40$ \\
\hline
\end{tabular}




\begin{tabular}{|l|l|}
\hline Mean $=45$ & Mean $=65$ \\
\hline $95 \%$ confidence interval for Mean: 41.67 thru 49.88 & $95 \%$ confidence interval for Mean: 62.04 thru 70.26 \\
\hline Standard Deviation $=14.3$ & Standard Deviation $=16.4$ \\
\hline $\mathrm{Hi}=60.0$ Low $=20.0$ & $\mathrm{Hi}=95$ Low $=35$ \\
\hline Median $=45$ & Median $=65$ \\
\hline $\mathrm{t}=6.99 / \mathrm{sdev}=13.0$ & \\
\hline
\end{tabular}

Table. 1 comparing the mean scores of two groups by one-sample T-test.

In order to answer the second research question (i.e. what are the advantages and disadvantages of the vocabulary techniques (e.g. flashcards vs. m-learning) utilized in the present study on the basis of the learner's experience?), the descriptive analytic stage was done after interviewing 10 participants of the experimental group and 10 participants of the control group.

The main extracted themes are as follow:

\begin{tabular}{l||l||}
\hline \multicolumn{1}{|c|}{ Advantages } & \multicolumn{1}{|c|}{ Disadvantages } \\
\hline \hline $\begin{array}{l}\text { Using spare time for learning vocabularies } \\
\text { (e.g. when waiting for the bus) / Students }\end{array}$ \\
are interested in the use of m-learning for some phones \\
vocabulary learning
\end{tabular}

Table 2: The results of the interview for the experimental group using mobile phones for vocabulary learning.

\begin{tabular}{|c|c|}
\hline Advantages & Disadvantages \\
\hline Flash cards are easy to use & $\begin{array}{l}\text { Difficult and abstract words are not } \\
\text { easy to be learned by flash cards }\end{array}$ \\
\hline $\begin{array}{l}\text { Flash cards can be used in games for } \\
\text { learning vocabularies }\end{array}$ & $\begin{array}{l}\text { The use of L1 may cause some } \\
\text { problems for the students while } \\
\text { remembering synonyms of the words }\end{array}$ \\
\hline New words can be practiced easily & $\begin{array}{l}\text { They have no access to any listening } \\
\text { part }\end{array}$ \\
\hline $\begin{array}{l}\text { Learners can separate words into } \\
\text { different categories }\end{array}$ & $\begin{array}{l}\text { They cannot listen to the } \\
\text { pronunciation }\end{array}$ \\
\hline Flash cards can be fun & $\begin{array}{l}\text { Having no review plan for flash cards } \\
\text { may cause lots of problems in } \\
\text { vocabulary learning }\end{array}$ \\
\hline
\end{tabular}


Table 3. The results of the interview for the control group using flash cards for vocabulary learning.

\section{Discussion and Conclusion}

The results of the present study demonstrate that using m-learning in vocabulary learning is more effective than using flashcards and it can foster the process of vocabulary learning in EFL settings. There are a number of advantages for using mobile phones in vocabulary learning. Firstly, students can learn anytime and anywhere. Secondly, students can receive instant feedback as they submit the right answer. Thirdly, they can surf the Internet and find different examples while encountering problems and mistakes. Fourthly, m-learning can increase the interaction among the learners, and between the learners and their teachers. Some of the students in the interview said that "we sent sms to each other periodically and checked the synonyms and antonyms... sometimes we surfed the net and found some idioms in which the new words had been used and we sent that idiom to all.

The findings of the present study are in line with a number of studies (e.g., Akbulut, 2007, Akbulut, 2008; Altun, 2005; Aydin, 2006; Aydin, 2007; Çakir, 2006; Hatipohlu Kavanoz, 2006; Kennedy and Levy 2008; Kocohlu, 2008; Saran, Cagiltay and Seferoglu, 2008; Song \& Fox, 2008) which found that EFL students have a positive attitude towards using mobile phones and computers in vocabulary learning. Additionally, Cavus and Ibrahim (2009) stressed that the use of short messages in EFL vocabulary learning can be a focal technique of vocabulary learning. Moreover, Thornton and Houser (2005) found similar results about the use of mobile phones in vocabulary learning. They compared m-learning and paper-based learning of vocabularies and found that $\mathrm{m}$ learning can be a better choice for learning vocabularies in an EFL setting.

This study shows that not only can mobile phones be used for communication in the year 2012, but they can also be used as effective devices for language learning. EFL students can use mobile phones for learning vocabularies, pronunciation and meanings in different contexts. Moreover, they can use these technologies wherever they like and whenever they think it is necessary to remember a meaning or synonym of a word. Nowadays, thanks to PDAs and finger touch mobile phones, the problem of small screen size has been solved and many ESL learners can enjoy the use of m-learning for vocabulary acquisition.

This study can suggest a number of implications for ESL/EFL practitioners. Although, flashcards were used as an effective way of teaching vocabulary, it should be noted that m-learning is a better strategy which should be utilized by EFL teachers in this age of technology. Accordingly, the use of this method in the EFL students' regular language learning program is highly recommended. All in all, teachers in EFL contexts should consider the use of different strategies for vocabulary learning. However, as shown in the present study, m-learning would be one of the best strategies in this regard.

\section{References}

Akbulut, Y. (2007). Variables predicting foreign language reading comprehension and vocabulary acquisition in a linear hypermedia environment. The Turkish Online Journal of Educational Technology, 6(1), 53-60.

Akbulut, Y. (2008). Exploration of the attitudes of freshman foreign language students toward using computers at a Turkish state university. The Turkish Online Journal of Educational Technology, 7(1), 18-31.

Akin, A., \& Seferoglu, G. (2004). Improving learners' vocabulary through strategy training and recycling the target words. Hacettepe University Journal of Education, 27, $1-10$. 
Ally, M. (2004). Intelligent tutoring systems for distributed learning. In F. O. Lin (Ed.), Designing Distributed Learning Environments with Intelligent Software Agents. Hershey, PA: Information Science Publishing, pp. 162-183.

Ally, M., Schafer, S., Cheung, B., McGreal, R., \& Tin, T. (2007). Use of mobile learning technology to train ESL adults. Paper included in the Proceedings of the 6th Annual International Conference on Mobile Learning, Melbourne, Australia, pp. 7-12.

Altun, A. (2005). Toward an effective integration of technology: message boards for strengthening communication. The Turkish Online Journal of Educational Technology, $4(1), 68-74$.

Attewell, J. (2005). Mobile technologies and learning: A technology update and mlearning project summary. London: Learning and Skills Development Agency.

Aydın, S. (2006). The effect of computers on the test and inter-rater reliability of writing tests of ESL learners. The Turkish Online Journal of Educational Technology, 5(1), 7581.

Aydın, S. (2007). The attitudes of EFL learners towards the Internet. The Turkish Online Journal of Educational Technology, 6(3), 18-26.

Baleghizadeh, S. \& Ashoori, A. (2011). The Impact of Two Instructional Techniques on EFL Learners' Vocabulary Knowledge: Flash Cards versus Word Lists. MEXTESOL Journal, 35(2), 70-82.

British Educational Communications Technology Agency. (2004). What the research says about portable ICT devices in teaching and learning: 2nd Edition Revised and Updated, Retrieved June 28, 2004, from

http://www.becta.org.uk/corporate/publications/documents/Research3_Portable\%20De vices.pdf

Brown, T. (2004). The role of m-learning in the future of e-learning in Africa. In D. Murphy, R. Carr, J. Taylor \& W. Tat-meng (Eds.), Distance education and technology: Issues and practice. Hong Kong: University of Hong Kong, pp. 197-216.

Bruton, A. (2007). Vocabulary learning from dictionary reference in collaborative EFL translational writing. System, 35, 353-367.

Bull, S., Cui, Y., Roebig, H., \& Sharples, M. (2005) Adapting to different needs in different locations: Handheld computers in university education. Wireless and Mobile Technologies in Education (IEEE). Tokushima, Japan: IEEE Computer Society.

Çakır, u. (2006). The use of video as an audio-visual material in foreign language teaching classroom. The Turkish Online Journal of Educational Technology, 5(4), 67-72.

Calderon, M., August, D., Slavin, R., Duran, D., Madden N., \& Cheung, A. (2005). Bringing words to life in classrooms with English-language learners. In E. H. Hiebert \& M. L. Kamil (Eds.), Teaching and learning vocabulary: Bringing research to practice. Mahwah, NJ: Lawrence Erlbaum Associates, pp. 115-136.

Cavus, N.,\& Ibrahim, D. (2009). m-Learning: An experiment in using SMS to support learning new English language words. British Journal of Educational Technology, 40(1), 78-91.

Cheung, A., \& Slavin, R. E. (2005). Effective reading programs for English language learners and other language-minority students. Bilingual Research Journal, 29(2), 241267. 
Davis, M., Good, N., \& Sarvas, R. (2004). From Context to Content: Leveraging Context for Mobile Media Metadata, Retrieved September 10, 2005, from http://sigmobile.org/mobisys/2004/context_awareness/papers/davis.pdf

Ehri, L. C., \& Roberts, K. T. (1979). Do beginners learn printed words better in context or in isolation? Child Development, 50(3), 675-685.

Erten, İ. H., \& Tekin, M. (2008). Effects on vocabulary acquisition of presenting new words in semantic sets versus semantically unrelated sets. System, 36, 407-422.

Esmahi, L., \& Lin, F. (2004). A multiagent framework for an Adaptive E-learning System. In F. Lin (Ed.), Designing Distributed Learning Environments with Intelligent Software Agents. Hershey, PA: Idea Group Publishing.

Folse, K.S. (2006). The effect of type of written exercise on L2 vocabulary retention. TESOL Quarterly, 40, 273-293.

Folse. K. S. (2004). Vocabulary Myths. Ann Arbor, MI: University of Michigan Press.

Genç, B. (2004). New trends in teaching and learning vocabulary. Çukurova Üniversitesi Sosyal Bilimler Enstitüsü Dergisi, 13(2), 117-126.

Hatipohlu Kavanoz, S. (2006). An exploratory study of English language teachers' beliefs, assumptions and knowledge about learnercenteredness. The Turkish Online Journal of Educational Technology, 5(2), 3-9.

Holzinger, A., Nischelwitzer, A., \& Meisenberger, M. (2005). Lifelong-learning support by m-learning: Example scenarios. E-learn Magazine. Retrieved December 1, 2005, from http://www.elearnmag.org/subpage. .fm?section=research\&article=6-1

Hulstijn, J.H. (2001). Intentional and incidental second language vocabulary Learning: a Reappraisal of Elaboration, Rehearsal and Automaticity. In P. Robinson (Ed.) Cognition and Second Language Instruction. Cambridge: Cambridge University Press, pp. 258286.

Hulstijn, J.H. \& Laufer B. (2001). Some empirical evidence for the involvement load hypothesis in vocabulary acquisition. Language Learning, 51,539-58.

Hunt, A., \& Beglar, D. (2005). A framework for developing EFL reading vocabulary. Reading in a Foreign Language, 17(1), 23-59.

Kawarasaki, M., Ooto, K., Nakanishi, T., \& Suzuki, H. (2004, January 26 - 30). Metadata driven seamless content handover in ubiquitous environment [Electronic Version]. International Symposium on Applications and the Internet (SAINT'04). Retrieved September 2, 2004, from

http://csdl.computer.org/comp/proceedings/saint/2004/2068/00/20680287abs.htm

Keegan, D. (2002). The future of learning: ZIFF papiere 119: From eLearning to mLearning. Retrieved http://www.fernuni-hagen.de/ZIFF/ZP_119.pdf

Kennedy, C. and Levy, M. (2008). L'italiano al telefonino: Using SMS to support beginners' language learning. ReCALL, 20, 315-330. doi:10.1017/S0958344008000530

Kocohlu, Z. (2008). Turkish EFL student role of electronic portfolios in their professional development. The Turkish Online Journal of Educational 79.

Kukulska-Hulme, A. \& Shield, L. (2008). An overview of mobile assisted language learning: From content delivery to supported collaboration and interaction. ReCALL, 20(3) , 271-289. doi:10.1017/S0958344008000335 
Kukulska-Hulme, A. (2009). Will mobile learning change language learning? ReCALL, 21(2), 157-165.

Larsen-Freeman, D. and Anderson, M. (2011). Techniques and principles in language teaching. Oxford: Oxford University Press.

Lee, S.H., \& Muncie, J. (2006). From receptive to productive: Improving ESL learners' use of vocabulary in a postreading composition task. TESOL Quarterly, 40, 295-320.

Lin, F. (Ed.). (2004). Designing Distributed Learning Environments with Intelligent Software Agents. Hershey, PA: Idea Group Publishing.

Lin, F., \& Esmahi, L. (2004). Integrating agent Technologies and web services into Distributed Learning Environments. In F. Lin (Ed.), Designing Distributed Learning Environments with Intelligent Software Agents. Hershey, PA: Idea Group Publishing.

Magusin, E., Johnson, K., \& Tin, T. (2003). Library services: Designing the digital reading room to support online learning [Electronic Version]. Proceedings of the19th Annual Conference on Distance Teaching and Learning. Retrieved March 31, 2005, from http://www.uwex.edu/disted/conference/Resource_library/proceedings/03_65.pdf

McCarten, J. (2007). Teaching vocabulary - Lessons from the corpus, Lessons for the Classroom. Cambridge University Press, [On-line]. Available from http://www.cambridge.org/other_files/downloads/esl/booklets/McCarten-TeachingVocabulary.pdf

McCullough, C. (1955). Flash cards-The opiate of the reading program? Elementary English, 32, 379-381.

McGreal, R., Cheung, B., Tin, T., \& Schafer, S. (2005) Implementing mobile environments using learning objects: The Athabasca University Digital Reading Room. IEEE International Workshop on Wireless and Mobile Technologies in Education Conference (WMTE) 2005. Tokushima, Japan: IEEE.

Moras, S. (2001). Teaching vocabulary to advanced students: A lexical approach, [Online]. Retrieved February 21, 2009 Available from http://www3.telus.net/linguisticsissues/teachingvocabulary.html

Nagy, W. E., P. A. Herman, and R. C. Anderson. (1985). Learning words from context. Reading Research Quarterly. 23, 122-134.

Nah, K.CH. , White, P. and Sussex, R. (2008). The potential of using a mobile phone to access the Internet for learning EFL listening skills within a Korean context. ReCALL, 20(3) , 331-347. doi:10.1017/S0958344008000633

Nam, J. (2010). Linking research and practice: effective strategies for teaching vocabulary in the ESL classroom. TESL Canada Journal/Revue TESL de Canada, 28(1), 127-135.

Nassaji, H. (2003). L2 vocabulary learning from context: Strategies, knowledge sources, and their relationship with success in L2 lexical inferencing. TESOL Quarterly, 37, 645670.

Nation, P. (2001). Learning vocabulary in another language. Cambridge, UK: Cambridge University Press.

Newton, J. (2001). Options for vocabulary learning through communication tasks. Oxford Journals, 55(1), 30- 37.

Nicholson, T. (1998). The flashcard strikes back. The Reading Teacher, 52(2), 188-192. 
Okunbor, D.,\& Retta, G. (2008). Analysis of a mobile learning pilot study. Math and Computer Science, 22, 120-135.

Oxford, R.L., \& Scarcella, R.C. (1994). Second language vocabulary learning among adults: State of the art in vocabulary instruction. System, 22(2),231-243.

Palka, E. (1988). Using cards to revise and practice language items. (ERIC Document Reproduction Service No. ED 302093).

Perry, D. (2000). Portable computers in primary schools: Literature review. London: Lambeth Education Action Zone. Psion netBooks Project.

Petersen, S. A., M. and Chabert, G. (2008). Identity, sense of community and connectedness in a community of mobile language learners. ReCALL, 20(3), 361-379. doi: $10.1017 /$ S0958344008000839

Qian, D. D. (2002). Investigating the relationship between vocabulary knowledge and academic reading performance: An assessment perspective. Language Learning, 52, 513-536.

Read, J. (1988). Measuring the vocabulary knowledge of second language learners. RELC Journal, 19(2), 12-25.

Saran, M., Cagiltay, K., \& Seferoglu, G. (2008). Use of mobile phones in language learning: Developing effective instructional materials. Proceedings of the 5th International Conference on Wireless, Mobile and Ubiquitous Technologies in EducationWMUTE2008, pp. 39-43.

Savill-Smith, C., \& Kent, P. (2003). The use of palmtop computers for learning: A review of the literature, Retrieved March 28, 2004, from http://www.m-

learning.org/docs/the_use_of_palmtop_computers_for_learning_sept03.pdf

Song, Y., \& Fox, R. (2005) Integrating m-technology into Web-based ESL vocabulary learning for working adult learners. Wireless and Mobile Technologies in Education (IEEE). Tokushima, Japan: IEEE Computer Society.

Song, Y., \& Fox, R. (2008). Using PDA for undergraduate student incidental vocabulary testing. ReCALL, 20(3), 290-314.

Stockwell, G. (2007). Vocabulary on the move: Investigating an intelligent mobile phone-based vocabulary tutor. Computer Assisted Language Learning, 20(4), 365-383.

Stockwell, G. (2008). Investigating learner preparedness for and usage patterns of mobile learning. ReCALL, 20(3), 253-270.

Tang, E., \& Nesi, H. (2003). Teaching vocabulary in two Chinese classrooms: Schoolchildren's exposure to English words in Hong Kong and Guangzhou. Language Teaching Research, 7(1), 65-97.

Taylor, R. (2005). Kenya pilots handheld education. BBC News. Retrieved August 4, 2005, from http://news.bbc.co.uk/2/hi/programmes/click_online/4727617.stm

Thornton, P., \& Houser, C. (2005). Using mobile phones in English education in Japan. Journal of Computer Assisted Learning, 21, 217-228.

Wesche, M., \& Paribakht, T. S. (1996). Assessing second language vocabulary knowledge: Depth versus breadth. Canadian Modern Language Review, 53, 13-40. 
Wishart, J. (2008). Challenges faced by modern foreign language teacher trainees in using handheld pocket PCs (Personal Digital Assistants) to support their teaching and learning. ReCALL, 20(3) , 348-360. doi:10.1017/S0958344008000736

White, A. (2005). Infusing PDA technology into nursing education. Nurse Educator. 30(4): $150-154$.

Yang, S. J. H., Shao, N. W. Y., \& Sue, A. Y. S. (2005) Personalized Metadata Mechanism Applied to Adaptive Mobile Learning. 2nd IEEE International Workshop on Wireless and Mobile Technologies in Education (WMTE'04). Retrieved September 10, 2005, from http://www.computer.org/portal/web/csdl/abs/proceedings/wmte/2004/1989/00/1989t oc.htm doi: 10.1109/WMTE.2004.1281377

Young, C. C., Hecimovic, A., \& Salzberg, C. L. (1983). Tutor-tutee behavior of disadvantaged kindergarten children during peer teaching. Education and Treatment of Children, 6(2), 123-135.

Top 